\title{
Plant Growth-Promoting Microorganisms in Coffee Production: From Isolation to Field Application
}

\author{
Narcisa Urgiles-Gómez ${ }^{1, *(1)}$, María Eugenia Avila-Salem ${ }^{2}{ }^{(0}$, Paúl Loján ${ }^{3}{ }^{(D}$, Max Encalada ${ }^{4}$, Leslye Hurtado ${ }^{1}$, \\ Salomé Araujo ${ }^{5}$, Yadira Collahuazo ${ }^{5}$, José Guachanamá ${ }^{6}$, Nohemy Poma ${ }^{6}$, Klever Granda ${ }^{6}$, Angel Robles ${ }^{6}$, \\ Carolina Senés ${ }^{7}$ (i) and Pablo Cornejo ${ }^{8, *}$ (1)
}

1 Carrera de Ingeniería Forestal, Universidad Nacional de Loja, Loja 110101, Ecuador; leslye.hurtado@unl.edu.ec

2 Facultad de Ciencias Agrícolas, Laboratorio de Química Agrícola de Suelos, Universidad Central del Ecuador, Quito 170521, Ecuador; mavila@uce.edu.ec

3 Departamento de Ciencias Biológicas y Agropecuarias, Universidad Técnica Particular de Loja, Loja 110101, Ecuador; pdlojan@utpl.edu.ec

4 Dirección de Investigación, Universidad Nacional de Loja, Loja 110101, Ecuador; max.encalada@unl.edu.ec

5 Centro de Biotecnología, Universidad Nacional de Loja, Loja 110101, Ecuador; lourdes.araujo@unl.edu.ec (S.A.); yadira.collahuazo@unl.edu.ec (Y.C.)

6 Carrera de Ingeniería Agronómica, Universidad Nacional de Loja, Loja 110101, Ecuador; jaguachanamas@unl.edu.ec (J.G.); laura.poma@unl.edu.ec (N.P.); klever.granda@unl.edu.ec (K.G.); angel.robles@unl.edu.ec (A.R.)

check for updates

Citation: Urgiles-Gómez, N.; Avila-Salem, M.E.; Loján, P.; Encalada, M.; Hurtado, L.; Araujo, S.; Collahuazo, Y.; Guachanamá, J.; Poma, N.; Granda, K.; et al. Plant Growth-Promoting Microorganisms in Coffee Production: From Isolation to Field Application. Agronomy 2021, 11, 1531. https://doi.org/10.3390/ agronomy11081531

Academic Editors: Jorge M. S. Faria, Clarisse Brigido and

Esther Menéndez

Received: 12 June 2021

Accepted: 26 July 2021

Published: 30 July 2021

Publisher's Note: MDPI stays neutral with regard to jurisdictional claims in published maps and institutional affiliations.

Copyright: () 2021 by the authors Licensee MDPI, Basel, Switzerland. This article is an open access article distributed under the terms and conditions of the Creative Commons Attribution (CC BY) license (https:// creativecommons.org/licenses/by/ $4.0 /)$.
7 Tecnológico de Monterrey, Escuela de Ingeniería y Ciencias, Zapopan 45201, Mexico; carolina.senes@itesm.mx

8 Centro de Investigación en Micorrizas y Sustentabilidad Agroambiental (CIMYSA), Universidad de La Frontera, Temuco 4811230, Chile

* Correspondence: narcisa.urgiles@unl.edu.ec (N.U.-G.); pablo.cornejo@ufrontera.cl (P.C.)

\begin{abstract}
Coffee is an important, high-value crop because its roasted beans are used to produce popular beverages that are consumed worldwide. Coffee plantations exist in over 70 countries and constitute the main economic activity of approximately 125 million people. Currently, there is global concern regarding the excessive use of agrochemicals and pesticides in agriculture, including coffee crops. This situation has motivated researchers, administrators, and farmers to seek ecologically friendly alternatives to decrease the use of synthetic fertilizers and pesticides. In the last decades, multiple studies of the rhizosphere, at the chemical, physical and biological levels, have improved our understanding of the importance of beneficial microorganisms to plant health and growth. This review aims to summarize the state of the use of plant growth-promoting microorganisms (PGPM) in coffee production, where the most extensively studied microorganisms are beneficial plant growthpromoting rhizobacteria (PGPR) and arbuscular mycorrhizal fungi (AMF). This review also contains information on PGPM, in regard to plantations at different latitudes, isolation techniques, mass multiplication, formulation methods, and the application of PGPM in nurseries, monoculture, and coffee agroforestry systems. Finally, this review focuses on relevant research performed during the last decade that can help us improve sustainable coffee production.
\end{abstract}

Keywords: coffee; microorganisms; plant-growth promoters; symbiotic association; PGPM; PGPR; AMF

\section{Introduction}

The soil is a complex system where multiple physical, chemical, and biological processes occur. Soil microorganisms play a key role in the maintenance of life in ecosystems, since they participate in important processes such as nutrient cycling and plant nutrition [1]. Microbial communities in the rhizosphere are complex and have crucial functions that contribute to the development of sustainable agricultural practices. Such microbial communities are included in the "rhizosphere microbiome" [2]. Among the most promising microorganisms for agricultural purposes are plant growth-promoting rhizobacteria 
(PGPR) and arbuscular mycorrhizal fungi (AMF), because of their well-known effects as plant-growth and health stimulators [3]. These characteristics allow PGPR and AMF to be considered suitable tools for sustainable agriculture, forestry, and restoration of degraded soils and plant communities [4-6]. It is well known that certain agronomic practices, such as excessive tillage, overfertilization, and hard application of pesticides, can decrease the efficiency and densities of native populations of beneficial microorganisms. In this context, inoculation of efficient PGPR strains as plant growth enhancers [7] and biocontrol agents [8] is considered to be an efficient strategy in agriculture and forestry [9]. Alternatively, practices such as polyculture, crop rotation and organic amendments can increase the populations of beneficial microorganisms. Plant growth-promoting microorganisms (PGPM) represent an interesting alternative for sustainable agriculture and forestry because PGPM can replace, to a certain degree, the dependence on external inputs, such as chemical fertilizers and pesticides [10-12]. The directed management of a symbiosis established between microorganisms and inoculated plants is a viable alternative for nursery production of commercial species such as coffee (Coffea arabica L.), when inert substrates, such as sand or turf, are commonly used. These substrates lack an efficient population of beneficial microorganisms that are needed in early plant growth and further performance. Under these conditions, inoculation with PGPM could be important. Nevertheless, inoculation success will depend on the effectiveness of the introduced microbial isolates, and on the formulation and the application method selected to incorporate PGPM into the substrate [13]. In the last two decades, modern biotechnologies and plant microbiome engineering have been applied to modify this microbiome towards a specific microbial community, allowing optimized crop growth, and thus increasing profitability. Moreover, beneficial plant-microbe interactions can be managed in order to increase crop production under field conditions. For instance, microbiome or rhizosphere engineering can be applied to traditional and emerging crop production systems, taking advantage of the ecosystem services that will improve crop yields and resilience [13-15]. Meanwhile, coffee is one of the world's favorite and most preferred beverages, with consumption rising at an annual growth rate of 3.6\%, and global production of green beans reaching $20.7 \mathrm{Mt}$ in 2019 [16]. The genus Coffea includes several botanical species; however, only the following two are cultivated for commercial purposes, mainly in tropical and subtropical regions worldwide: Coffea arabica L. (arabica) and Coffea canephora Pierre ex Froenher (robusta), which are the most important species worldwide in terms of cropped area. Coffee production is a commercial activity that allows biological conservation, since the growth of coffee plants promotes biodiversity due to the number of shrubs that are required to provide shade to coffee plants and protection from direct sunshine. Coffee plantations enhance environmental conservation by becoming habitats for different plant and animal species, as well as PGPM, including AMF [4,5]. Moreover, from an economic point of view, coffee production also generates employment and income for families and other actors in the value chain [10].

This review summarizes advances in the study of PGPM in coffee production, including the reported microbial diversity associated with coffee plants, microbial isolation, mass multiplication, inocula formulation techniques, and methods for application in nurseries, agroforestry systems, agroecological systems, and conventional monocultures. For this review, scientific articles related to the use of beneficial microorganisms, such as PGPR and AMF in coffee production, primarily published during the last decade, were considered. Finally, some consideration is given to improving the current management of coffee crops and moving towards a more resilient production system by including advanced biotechnological tools based on the incorporation of PGPR and AMF in the production chain.

\section{Diversity of PGPR Associated with Coffee Plantations in Different Geographical Areas}

PGPR were initially described as a type of bacteria with plant growth-promoting capabilities that resisted plant pathogens. Among them, the genera Alcaligenes, Pseudomonas, Azospirillum, Bacillus, Klebsiella, Azotobacter, Enterobacter, Gluconacetobacter, Burkholderia, 
Arthrobacter, Rhizobium, Bradyrhizobioum, and Serratia are the most studied [13]. To date, several studies have demonstrated that when PGPR are inoculated in the soil or seeds, using appropriate methods (e.g., efficient strains, suitable formulation and inoculation strategies, and suitable agronomic practices, etc.), in addition to controlling plant pathogens, they can improve nutrient absorption, root and shoot formation, seed germination, plant tolerance to environmental stress, nitrogen $\left(\mathrm{N}_{2}\right)$ fixation, and phosphate solubilization [14]. PGPR also influences the secretion of phytohormones (indole acetic acid-IAA, gibberellins, cytokinins, and ethylene) [17-19]. In summary, PGPR fulfil the following three important functions: (1) biocontrol, through antagonistic effects against soil-borne diseases; (2) biofertilization, by increasing the availability of nutrients such as $\mathrm{N}$ or P; and (3) biostimulation, through the production of hormones such as auxins or giberelins. It has been reported that under normal conditions, the concentration of bacteria in the rhizosphere is approximately $10^{12}$ colony forming units (CFU) $\mathrm{g}^{-1}$, but under intense environmental stress, the concentration decreases to $10^{4} \mathrm{CFU} \mathrm{g}^{-1}$ [19].

In coffee plantations from Mexico, Acetobacter diazotrophicus, a strict aerobic Gramnegative bacterium that favors $\mathrm{N}_{2}$ fixation, as is an endosymbiont, has been isolated from coffee plant tissues and rhizosphere soils [20]. In Ethiopia, Kejela et al. [21] reported the isolation of Bacillus amyloliquefaciens BT42 from root rhizosphere, a Gram-positive bacterium that is able to inhibit the growth of the pathogenic fungi Colletotrichum gloeosporioides and Fusarium oxysporum, which are two of the most important pathogens in coffee plantations. B. amyloliquefaciens BT42 has also been described as a powerful biofertilizer, given its strong plant growth-promoting effects. In Peru, Azospirillum amazonense, Azospirillum sp., Pseudomonas putida and Burkholderia gladioli were isolated from the coffee rhizosphere, and these bacteria displayed a series of plant growth-promoting traits. Among the traits reported, bacteria of the Azospirillum genus were linked to noticeable biological $\mathrm{N}_{2}$ fixation, phosphate solubilizing activities, and high rates of auxin production; Pseudomonas also solubilized phosphates, and a Burkholderia strain had the capability to produce indolic compounds [22].

In Colombia, Kocuria sp. and Bacillus subtilis were found to be phosphate solubilizing bacteria that improved the development of coffee seedlings and phosphorus availability in the soil [23]. Bacillus subtilis strains AP-3 and AP-150, isolated from the rhizosphere, showed biocontrol activity by preventing the urediniospore germination of different Hemileia vastatrix strains, another important foliar pathogen (rust) of coffee plants [24], while Azotobacter sp. isolates produced indol 3-acetic acid (IAA) that stimulated plant cell elongation and division [25]. Furthermore, in Brazi Bacillus, a study revealed that the precursor effect of flavor in coffee beans occurred due to the presence of Bacillus subtilis with guaiac production, and the presence of Arthrobacter koreensis with production of malic, lactic and acetic acids [26].

In Ethiopia, the phosphate solubilizing activity of Erwinia sp. was described when applied as a bioinoculant in acidic soils. Also, the presence of Burkholderia sp. in the coffee rhizosphere improved nutrient uptake and had a biocontrol effect through the production of siderophores, antibiotics and antifungal compounds [27]. Studies in India showed that $\mathrm{N}_{2}$ fixation by Azospirillum sp. stimulated the proliferation of lateral roots, which increased aeration, facilitated soil moisture control, and improved overall crop development and nutrition [28]. Under in vitro conditions, the biofertilizer capability of Acinetobacter calcoaceticus was corroborated by means of phosphatase activity and IAA production. In addition, Serratia marcescens was found to produce chitinase, which had antifungal activity against Rhizoctonia solani and Fusarium oxysporum [29]. Moreover, PGPR isolated from Coffea arabica showed potential as biofertilizers and biopesticides [30]. These species of PGPR are safe to use because they do not pose a risk to flora and fauna, or to consumer health, because they do not bioaccumulate in crop products [31,32]. In Table 1, various species of PGPR are detailed, as well as their mode of action in coffee grown at different latitudes. 
Table 1. Geographic diversity of PGPR and its mode of action in coffee crops and quality of the beans.

\begin{tabular}{|c|c|c|c|}
\hline PGPR & Role and Mode of Action in Soil, Plant/Seed Quality & Country & Reference \\
\hline Acetobacter diazotrophicus & Biofertilization mainly through $\mathrm{N}_{2}$ fixation & Mexico & [20] \\
\hline Bacillus amyloquefaciens BT42 & $\begin{array}{l}\text { Biocontrol, biostimulation and biofertilization through antagonism } \\
\text { to Colletotrichum gloeosporioides and F. oxysporum, IAA production, } \mathrm{P} \\
\text { solubilization, production of siderophores and ACC deaminase }\end{array}$ & Ethiopia & [21] \\
\hline $\begin{array}{l}\text { Azospirillum amazonense } 1 \mathrm{I} \\
\text { Azospirillum sp. 1A }\end{array}$ & $\begin{array}{c}\text { Biostimulation and biofertilization through } \mathrm{N}_{2} \text { fixation, } \mathrm{P} \\
\text { solubilization and IAA production }\end{array}$ & Peru & [22] \\
\hline Pseudomonas putida 2G & $\begin{array}{l}\text { Biostimulation, biofertilization through } \mathrm{N}_{2} \text { fixation, P solubilization } \\
\text { and IAA production }\end{array}$ & Peru & [22] \\
\hline Burkholderia gladioli 2C & $\begin{array}{c}\text { Biostimulation and biofertilization through } \mathrm{N}_{2} \text { fixation, } \mathrm{P} \\
\text { solubilization and IAA production }\end{array}$ & Peru & [22] \\
\hline Kocuria sp. & $\begin{array}{c}\text { Biofertilization through P solubilization and improvement of the } \\
\text { development of coffee seedlings }\end{array}$ & Colombia & [23] \\
\hline Bacillus subtilis & $\begin{array}{l}\text { Biofertilization thorugh P solubilization and improvement of the } \\
\text { development of coffee seedlings }\end{array}$ & Colombia & [23] \\
\hline $\begin{array}{l}\text { Bacillus subtilis AP-3 and } \\
\text { AP-150 }\end{array}$ & $\begin{array}{c}\text { Biocontrol by preventing the germination of urediniospores from } \\
\text { various breeds of Hemileia vastatrix }\end{array}$ & Brasil & {$[24]$} \\
\hline Azotobacter sp. & $\begin{array}{c}\text { Biofertilization and biorremediation through } \mathrm{N}_{2} \text { fixation and } \\
\text { endosulfan degradation }\end{array}$ & Colombia & [25] \\
\hline Bacillus subtilis & $\begin{array}{l}\text { Seed quality precursor. } \\
\text { Guaiac/Guaicol/Flavor enhancer in coffee beans } \\
\text { Seed quality precursor. }\end{array}$ & Brasil & [26] \\
\hline Arthrobacter koreensis & $\begin{array}{c}\text { Malic, lactic and acetic acid production/flavor marker precursor in } \\
\text { coffee beans }\end{array}$ & Brasil & [26] \\
\hline Erwinia sp. & Biofertilization through $\mathrm{P}$ solubilization in acidic soils & Ethiopia & [27] \\
\hline Azospirillum sp. & Biofertilization through $\mathrm{N}_{2}$ fixation and proliferation of lateral roots & India & [28] \\
\hline Acinetobacter calcoaceticus & $\begin{array}{l}\text { Biofertilization through P solubilization and IAA production } \\
\text { in vitro }\end{array}$ & Malasia & [29] \\
\hline
\end{tabular}

\section{PGPR Isolation, Multiplication, and Inoculum Formulation}

Few studies have been carried out globally to determine the identity of bacterial consortia associated with coffee cultivation. These studies are of great importance, and they aim to discover new species that establish beneficial associations with Coffea plants. As previously mentioned, among PGPR reported in the rhizosphere of Coffea spp., the genera Rhizobium, Azotobacter, Azospirillum, Acetobacter, Pseudomonas, Erwinia, Bacillus, and Burkholderia are consistently present $[21,25,27,33]$. With further analysis and common protocols, the above bacteria could be isolated, identified, and formulated as biofertilizers. Nevertheless, there is little information regarding the isolation, characterization and identification of PGPR from the coffee plant rhizosphere. Alcarraz et al. [22] recently reported the isolation and identification of native strains of PGPR from coffee plant rhizospheres. The bacteria were pre-enriched in modified nitrogen-fixing bacteria $(\mathrm{NFb})$ liquid medium for 5 days at $28{ }^{\circ} \mathrm{C}$. After bacterial growth, a serial dilution in $0.85 \%$ saline solution and inoculation by striae depletion $\left(10^{-3}-10^{-5}\right.$ dilutions), in Petri dishes with NFb solid culture medium, were performed. Other studies with isolation and characterization of PGPR from different coffee management systems were carried out in Ethiopia by Muleta et al. [27]. In both cases, the bacteria were described in terms of cell and colony morphologies, considering the elevation, margin, surface, and opacity. To complement these characterizations, the researchers performed Gram staining and biochemical tests for oxidase, catalase, $\mathrm{KOH}$ and urease activity. The pure isolates were stored at $4^{\circ} \mathrm{C}$ for later analysis. A key point in the isolation of PGPR from the coffee rhizosphere is obtaining effective strains to be used as biofertilizers. In this regard, Alcarraz et al. [22] and Muleta et al. [27] determined bacterial strains with the ability to fix $\mathrm{N}_{2}$ through the indirect ammonium ion titration method, using the Berthelot colorimetric technique. The researchers also determined and quantified the production of IAA and the ability of the isolated strains to solubilize inorganic phosphates under in vitro conditions [34]. Based on molecular analyses, Alcarraz 
et al. [22] reported PGPR strains of the genera Azospirillum, Pseudomonas, and Burkholderia, while Muleta et al. [27] described a diversity of bacterial genera associated with coffee plants, including Pseudomonas, Bacillus, Erwinia, Ochrobactrum, and Serratia spp. (Table 1).

Strains displaying plant growth-promoting traits, such as those described by Alcarraz et al. [22] and Muleta et al. [27], have not been reported in the formulation of biofertilizers, and have received much less evaluation under field conditions and in agricultural systems with Coffea arabica. However, a few other studies reported the use of PGPR strains as biofertilizers in coffee cultivation [35]. Aguirre-Medina et al. [36] reported the use of a biofertilizer based on the bacterial strain Azospirillum spp., inoculated in coffee plants in Mexico, and its application showed positive effects on plant growth and development. Likewise, the application of a biological inoculant called Graminante ${ }^{\mathrm{TM}}$, which is marketed as a powder mixed with calcium carbonate for biofertilization in coffee plants, has been reported in Uruguay [37].

Several studies of PGPR bioformulation have occurred for other crops of agricultural interest and suggest that a well-defined solid support should be considered to allow the survival of a high number of viable cells until the moment of application [38,39]. The carriers used are based on peat, clay, organic amendments, inert materials, such as vermiculite, crushed rock phosphate, polyacrylamide gels, liquid osmoprotectants, and alginate, among other polymers [40]. When PGPR are formulated with an organic support, stability and durability are increased. In addition, the application to seeds becomes easier and more practical [41]. Liquid inoculants are also constituted as complete microbial suspensions, based on water, oil, or polymers that can increase adherence, stability, stress tolerance, and dispersion capacity [42]. The main advantages of liquid inoculants are easier processing and lower costs compared to solid-based formulations [42,43].

In this context, the formulation of inoculants that include PGPR can improve the growth characteristics of plants, concomitantly decreasing the use of chemical fertilizers. The best formulation, from a biological point of view, is to use active products that contain consortia with one or more beneficial strains. However, more studies are required to evaluate bacterial survival under nursery and field conditions, as well as to determine the response and compatibility of different crops, such as Coffea arabica, to the application of biological inoculants [34].

\section{Diversity of AMF Associated with Coffee Crops}

Arbuscular mycorrhizal fungi (AMF) generate mutualistic relationships with plants, where fungi supply plants with nutrients and water, and plants provide carbon to fulfil the needs of the fungal partner $[5,23,36,44]$. AMF are cosmopolite with a wide distribution, colonizing up to $85 \%$ of all vascular plant species (including coffee) across vegetated terrestrial biomes $[12,45]$.

Human activities, such as logging, agriculture, and urbanization, have altered 50-75\% of the Earth's terrestrial ecosystems, and modified AMF frequency, diversity, and community structure [10,12,45]. It is widely known that the global distribution and diversity of AMF depend on plant biomes and climate factors, local environmental and soil conditions, AMF taxon interactions and dispersal limitations [46].

In Costa Rica, a survey carried out by Prates-Júnior et al. [37], on AMF communities associated with coffee roots, included soil samples from 25 plots, with organic management, shade, and no use of fertilizers compared to plots under conventional management, with little shade and high $\mathrm{N}$ fertilization. This study indicated that the Gigasporaceae and Acaulosporaceae families were dominant in abundance and richness. The richness of Gigasporaceae was higher in the conventionally managed plots, while that of Glomeraceae was higher in the organically managed plots. The Gigasporaceae family was associated with more daylight and $\mathrm{N}$ availability, while Acaulosporaceae was generally associated with lower $\mathrm{N}$ availability. Among the identified species were Rhizophagus fasciculatus, Glomus indicum, Claroideoglomus etunicatum, Gigaspora margarita, Acaulospora scrobiculata, Acaulospora minuta, and Acaulospora laevis. 
On the other hand, [37] in Brazil reported the presence of the following AMF species in soil related to coffee plants: Glomus sp., Gl. spinuliferum, Gl. fuegianum, Gl. glomerulatum, Gl. aggregatum, Acaulospora sp., Ac. mellea, Ac. sieverding, Ac. tuberculata, Ac. scrobiculata, Ac. herrerae, Ac. foveate, Ac. nivalis, Ac. verna, Ac. morrowiae, Ac. denticulate, Scutellospora sp., Sc. pernambucana, Archaeospora trappei, Ambispora leptoticha, Am. leptoticha, Gigaspora sp. 1, Rhizophagus fasciculatus, Dentiscutata biornata, De. cerradensis, and Paraglomus occultum. In this study, plots with agroecological and conventional management, and forest fragments, were compared. Molecular analysis indicated a higher diversity index in agroecological and agroforestry systems than in plots under conventional management, providing new evidence about the strong impact of agricultural management systems on AMF communities.

Vallejo-Torres et al. [47], working with the coffee variety "Caturra" in crops from Perú, reported a positive effect of the use of an AMF consortium, on plant height, foliar area and root biomass, as well as a positive effect on root colonization capacity and extraradical mycelium density. Among the AMF species found were Acaulospora rugosa, Ac. foveata, Ac. mellea, Ac. tuberculata, Ac. rhemii, Acaulospora sp., Glomus sp. 1., Glomus sp. 2, Gl. geosporum, Gl. Sinuosum, and Ambispora appendicula. Another study of coffee crops from Perú [48] reported Glomus brohultii, Gl. fuegianum, Funneliformis geosporum, Claroideoglomus claroideum, Glomus sp., Scutellospora sp., Sclerocystis sp., and Acaulospora mellea as the most common species.

Mahdi et al. [49] studied the diversity of AMF in roots from coffee trees growing in Saudi Arabian soils. After molecular and phylogenetic analyses, Glomus was reported as the predominant genus, followed by Claroideoglomus, Acaulospora, and Gigaspora. DNA sequence data revealed similarity with Claroideoglomus claroideum, Glomus microaggregatum, G. mosseae, Rhizophagus intraradices, Gigaspora rosea, and Acaulospora longula. These findings constitute an important starting point for the proper development of bioinoculants for coffee plantations.

In Ecuador, Gavilanes [50] reported Funneliformis mosseae, Gigaspora gigantea, and Stecullospora spp. as the most common species in seedlings of Coffea canephora. On the other hand, in Colombia, Barrera et al. [35] reported Acaulospora, Glomus, and Scutellospora genera as the most abundant species, followed by Sclerocystis, Gigaspora, and Entrophospora in coffee cultivation.

A study carried out by Urgiles-Gomez [51] in the province of Loja (Southern Ecuador) included the pot culturing and isolation of AMF from field samples in agroforestry systems associated with coffee, with the purpose of identifying spore morphotypes at genus level, and obtaining inoculations for further experiments. Several spore morphotypes were described, belonging mainly to the genus Acaulospora and Glomus.

\section{AMF Isolation, Reproduction and Inoculum Formulation}

In recent decades, AMF have attracted attention from farmers and ecologists, due to the potential to improve plant performance in agricultural production and in ecosystem restoration [52]. Usually, the application of AMF to coffee plants is carried out during the early development of the plants [53]. Regardless of the aim of AMF inoculum production, the isolation and characterization of AMF is the first step to produce AMF-based inoculants [54]. It is known that some AMF are non-host specific and that under certain conditions and crops, they can promote plant growth and health, and enhance soil physical, chemical and biological properties $[12,55,56]$. As shown in the previous section, different studies have focused on the diversity of AMF associated with coffee plants. Among the 334 species of AMF described to date (amf-phylogeny.com), only a few (Rhizophagus intraradices, $R$. irregularis, and Funneliformis mosseae) are massively exploited commercially to produce inocula [57]. These species have been selected due to their (a) wide distribution, (b) generalist behavior, (c) ability to colonize a broad range of hosts, and (d) ease of maintenance and multiplication under in vivo or in vitro conditions.

Although the techniques to identify AMF have evolved rapidly, the methods to isolate these microorganisms have remained relatively unchanged in the past decade. 
The standard method to isolate AMF in pure cultures begins with the establishment of "trap cultures" that consist of a mixture of different species of AMF. Normally, after six months, the substrate in the trap cultures contains hundreds to thousands of AMF spores in one hundred grams of soil. Obviously, these cultures include a mix of different AMF. In order to isolate specific AMF species, multiple attempts using single spores inoculated in a mycorrhizal-free host plants (e.g., Plantago lanceolata) should be carried out. The success of isolation attempts is evaluated after 3-4 months through root staining. The AMF isolate effects on coffee plants are evaluated through physiological, metabolic and bio-chemical experiments through pots or in vitro experiments [58]. To select promising AMF consortia for coffee plants, the isolated AMF strains should be tested in greenhouse and field experiments, to compare their effects on plant performance and/or health. After the correct identification of isolated AMF strains, massive production is necessary for further formulation of single-based or mixed consortia of different AMF strains. We can define a formulation as a mixture of propagules (e.g., spores, hyphae, colonized roots) and a carrier or material for the efficient delivery of mycorrhizal inoculum [59]. As the performance of single AMF can vary under different conditions or coffee cultivars, it is important to develop native AMF consortia.

Although vegetative propagation of coffee is the best way to preserve the genetic characteristics of high-quality plants, most producers still propagate the plants directly from seeds [60]. In the field, coffee seeds emerge after 50-60 days after sowing, but under optimal conditions germination starts after 10 days [61]. The regular process to germinate coffee seeds is in trays with turf or sand. After germination, when the seedlings are in the matchstick stage or butterfly state (seedling and up to 40-50 days after sowing), plants are transplanted to bags containing an appropriate substrate [62], this being the best stage for the inoculation of coffee plantlets. For the inoculation of plants, it is necessary to develop a cost-efficient formulation, and one that is easy to apply in the nursery stage. The inoculum can be a solid formulation (e.g., powder, granular or pellet form) placed in the hole where the root of the coffee seedling will be placed. This method is routinely practiced in nurseries for trees [4]. The formulation will depend on the method of application in the plants (i.e., bare-root inoculation, bare-root soil inoculation, transplant inoculation, or root inoculation). The most commonly used carriers for AMF inocula produced in beds are sand, perlite, and vermiculite, in order to give them a solid consistency (e.g., granular, powder, or pellet form). For high-quality AMF propagules that are produced in vitro for commercial purposes, the formulation can be prepared with solid materials in the form of pellets, tablets, or granules [59]. Commercial inoculants containing AMF are also available in the market [63], but a previous analysis to evaluate its efficiency should be carried out.

\section{PGPR and AMF Use in Coffee Nurseries and Crops}

Pests and pathogens can cause irreversible damage to coffee crops. One of the main pests is the coffee berry borer (CBB) (Hypothenemus hampei Ferrari). Several studies of its biological control have been carried out. For instance, Zorzetti et al. [64] used 34 Bacillus thuringiensis strains, but only 11 strains achieved larval mortality higher than $96 \%$, with a medium lethal concentration (MLC) of $7.0 \times 107$ CFU. Similarly, biocontrols of diseases, such as rust (Hemileia vastatrix), leaf spot (Cercospora coffeicola Berkeley and Curtis), and American leaf spot (Mycena citricolor Berkeley and Curtis) [65], have been studied. RamirezRodriguez et al. [66] carried out experiments with Trichoderma harzianum as a biofungicide for the control of coffee rust, and obtained a considerable decrease in the severity of the disease. Likewise, Cacefo et al. [67] studied the biological control of $H$. vastatrix with $B$. subtilis, and the possible effects on plant performance. The results showed that $B$. subtilis effectively controlled the severity of rust, and did not produce morphological, anatomical, chemical, or physiological injuries in coffee plants.

Vallejos-Torres et al. [47] evaluated the inoculation of coffee clones of var. Caturra, with three AMF consortia from three different localities in Peru and two doses of compost (100 and $200 \mathrm{~g}$ ). Consortium 1 contained Acaulospora sp., A. scrobiculata, A. rhemii., Glomus sp2, 
and Glomus aggregatum. Consortium 2 contained A. rugosa, A. foveata, A. mellea, Glomus sp1., G. geosporum, G. sinuosum., Glomus sp2., and Ambispora appendicula. Consortium 3 contained Acaulospora sp., A. tuberculata, A. rhemii, A. foveata., Glomus sp2., and G. geosporum. For the multiplication of inocula, the authors used Zea mays as the host plant. Each plant was inoculated with approximately 3000 spores, and the control treatment contained neither AMF inoculum nor compost. At 295 days after sowing, the evaluated traits were plant height, number of branches, AMF colonization, extraradical mycelium, and number of AMF spores. The results showed that consortium 3, together with the addition of $100 \mathrm{~g}$ of compost per plant, significantly improved the plant height, number of branches, and extraradical mycelium of AMF. These results could suggest that using an appropriate AMF consortium together with a low amount of organic fertilizer are sustainable management options to improve coffee performance.

In the study by Dias-Moreira et al. [9], the effects of four doses of phosphorus (0.0, $0.32,0.65$, and $1.3 \mathrm{~g} \mathrm{P} \mathrm{kg}^{-1}$ ) and three AMF (Rhizophagus clarus, Claroideoglomus etunicatum, Dentiscutata heterogama) on the development of the coffee seedlings of var. Catuaí Vermelho IAC 99, growing in non-sterile soil, were evaluated. The evaluated traits were plant height, leaf area, and root dry mass. At 150 days after the establishment of the experiment, the results showed a significant increase in all the evaluated traits in AMF-inoculated plants, but this effect depended on the P dose. At P doses higher than $0.32 \mathrm{~g} \mathrm{P} \mathrm{kg}^{-1}$, the benefit associated with AMF decreased. Specifically, the AMF R. clarus and C. etunicatum promoted more efficient plant growth at low P levels than D. heterogama.

Fonseca et al. [54] evaluated the effect of Rhizophagus clarus inoculation on the initial development and nutritional response of six genotypes of Coffea arabica (MGS Aranas; H29-1-8-5; Red Catuai IAC 144; IPR 100; Catigua MG2; and Paraíso H 419-1) in Lavra, Brazil. Here, Brachiaria decumbens was used as a host plant for AMF trap cultures. After 150 days, the AMF-inoculated plants showed a height increase of $11.6 \%$, and an increase of $9.5 \%$ after 300 days, compared to the non-inoculated plants. Stem diameter increases in the genotypes Red Catuai IAC 144, IPR 100 and Catigua MG2, of 88.5, 99.2 and 35.4\%, respectively, were reported. Furthermore, on average, AMF colonization ranged between 34 and $62 \%$. The highest accumulation of $\mathrm{N}$ was in Red Catuai IAC 144 and IPR 100, and the highest $\mathrm{P}$ accumulation was in IPR 100, Catigua MG2 and H 29-1-8-5. These results suggest that a functional compatibility between $R$. clarus and plant genotype can be present, and indicate the importance of studying functional compatibility at the genotypic level.

In another study by Fonseca et al. [53], the effect of AMF on the acclimatization of two clones of Coffea arabica produced by somatic embryogenesis was evaluated under greenhouse conditions. Clone 1, "fruiting Catucaí", and Clone 2, "Acauã", were subjected to inoculation with (T1) R. clarus, (T2) Gigaspora margarita, (T3) Acaulospora mellea, (T4) a mixture of $R$. clarus and G. margarita, (T5) a mixture of $R$. clarus, G. margarita and $A$. mellea, and a control treatment without AMF. For the multiplication of AMF, Brachiaria decumbens was used as a trap plant. At transplantation, the clones were inoculated with 50 $\mathrm{mL}$ of AMF inoculant containing approximately 600 spores, hyphae, and colonized root segments. At six months, shoot height, stem diameter, leaf area, total chlorophyll, shoot dry mass, root dry mass, and total dry mass were evaluated. The results differed between the clones when inoculated with different AMF. For example, the height of the shoots of Clone 1 inoculated with AMF showed values that were 20.4 to $41.7 \%$ higher than those of the non-inoculated control plants, but no significant differences were observed among the treatments in Clone 2. The AMF-inoculated plants of Clone 1 showed better results on the overall evaluated parameters compared to the corresponding non-inoculated plants. The plants belonging to Clone 2 were less responsive to the different AMF treatments in most of the cases, and the differences between the inoculated and non-inoculated plants were not statistically significant. Therefore, the seedlings from Clone 1 presented a better response to inoculation than the seedlings from Clone 2, highlighting the importance of finding appropriate combinations between coffee cultivars and AMF. As evidenced in the abovementioned studies, inoculation with AMF can increase coffee performance under 
nursery or greenhouse conditions, but to promote the positive effect of AMF, it is important to take into account certain considerations, such as low doses of organic amendments [47], low doses of P [9], and suitable coffee variety-AMF combinations [53,54].

Finally, most studies on the use of AMF and other PGPM in coffee plants $[51,62,68]$ considered the first growth stages (nursery, transplanting), but less known are the long-term effects that could influence other noticeable productive and commercial characteristics, such as grain yield and quality, and especially organoleptic traits. Therefore, there is plenty of space for new research focusing on the improvement of coffee crop management using sustainable agricultural tools, such as bioinoculants designed à la carte for use in coffee production.

\section{Conclusions}

Plant growth-promoting microorganisms that are associated with coffee are important components of microbial biomass under monoculture and agroforestry systems in all geographical areas where coffee is cropped. In particular, AMF have been associated with clear improvements in nutrient uptake and tolerance to water stress by coffee plants, which are of ecological and economic importance. Moreover, plant growth-promoting rhizobacteria can support increased nitrogen fixation, which is especially relevant for the growth of coffee plants. Nevertheless, there are only a few studies analyzing the indigenous communities of these microorganisms in coffee plantations, even though coffee is an important commodity in over 50 countries that are involved in its production, trade and consumption. Based on the above, PGPR and AMF are potential resources for bioinoculant production, especially considering the use of indigenous soil microorganisms that are adapted to site-limiting conditions, thus increasing the functional characteristics of microorganisms that improve sustainable coffee production. Given the importance of AMF and PGPR as highly efficient agents for the performance of host plants, a deeper understanding of these important microbial groups must be acquired in the near future for coffee production. The methods for producing, formulating, and inoculating AMF and PGPR remain largely unexplored. Hence, it is important to develop research at the local level in different regions of the world, taking into consideration AMF and PGPR inoculation or reinoculation frequency needs to coffee seeds or plantlets, seasonality, type of soil, or inoculation substrate in the greenhouse, among many other factors. This research must also include the search for specific combinations of AMF and PGPR, to maximize their use as biological tools and also to efficiently contribute to sustainable coffee production, minimizing the dependence on chemical fertilizers.

Author Contributions: Conceptualization: N.U.-G.; writing-original draft preparation: N.U.-G., M.E.A.-S., P.L., M.E., L.H., S.A., Y.C., J.G., N.P., K.G., A.R., C.S.; writing-review and editing: P.C., M.E.A.-S., N.U.-G., P.L.; supervision and project administration: N.U.-G. and P.C.; funding acquisition: P.C. All authors have read and agreed to the published version of the manuscript.

Funding: This review is part of a research funded by the Research Department from the Universidad Nacional de Loja, Ecuador, through the grant 10-6-DI-FARNR-2019 "Isolation and molecular characterization of beneficial microorganisms from agroforestry systems of coffee plantations in the Ecuador region" (N.U.-G.), the Universidad Central del Ecuador, through the Doctoral Research grant No. 304 (M.E.A.-S.), the Vicerrectorado de Investigación of the Universidad Técnica Particular de Loja for the financial support through the grant PROY_INNOV_CCBIO_2019_2600 (P.L.), and Agencia Nacional de Investigación y Desarrollo, ANID, Chile, through the grants ANID/FONDAP/15130015 and ANID/FONDECYT/1170264 (P.C.).

Institutional Review Board Statement: Not applicable.

Informed Consent Statement: Not applicable.

Data Availability Statement: No new data were created or analyzed in this study. Data sharing is not applicable to this article. 
Acknowledgments: The authors acknowledge the manuscript's criticisms given by Antonieta Ruiz and Cledir Santos, from Universidad de La Frontera, Chile.

Conflicts of Interest: The authors declare no conflict of interest.

\section{References}

1. Brady, N.C.; Weil, R.R. The soils around us. In The Nature and Properties of Soils, 14th ed.; Pearson Prentice Hall: Upper Saddle River, NJ, USA, 2008; pp. 1-31.

2. Rout, M.E.; Southworth, D. The root microbiome influences scales from molecules to ecosystems: The unseen majority. Am. J. Bot. 2013, 100, 1689-1691. [CrossRef]

3. Desai, S.; Kumar, G.P.; Amalraj, L.D.; Bagyaraj, D.; Ashwin, R. Exploiting PGPR and AMF biodiversity for plant health management. In Microbial Inoculants in Sustainable Agricultural Productivity; Springer: Berlin/Heidelberg, Germany, 2016; pp. 145-160.

4. Schüßler, A.; Krüger, C.; Urgiles, N. Phylogenetically diverse AM fungi from Ecuador strongly improve seedling growth of native potential crop trees. Mycorrhiza 2016, 26, 199-207. [CrossRef] [PubMed]

5. De Beenhouwer, M.; Van Geel, M.; Ceulemans, T.; Muleta, D.; Lievens, B.; Honnay, O. Changing soil characteristics alter the arbuscular mycorrhizal fungi communities of Arabica coffee (Coffea arabica) in Ethiopia across a management intensity gradient. Soil Biol. Biochem. 2015, 91, 133-139. [CrossRef]

6. Babushkina, E.A.; Belokopytova, L.V.; Grachev, A.M.; Meko, D.M.; Vaganov, E.A. Variation of the hydrological regime of Bele-Shira closed basin in Southern Siberia and its reflection in the radial growth of Larix sibirica. Reg. Environ. Chang. 2017, 17, 1725-1737. [CrossRef]

7. Bünemann, E.K.; Schwenke, G.; Van Zwieten, L. Impact of agricultural inputs on soil organisms-A review. Aus. J. Soil Res. 2006, 44, 379-406. [CrossRef]

8. Janušauskaite, D.; Kadžienè, G.; Auškalnienè, O. The effect of tillage system on soil microbiota in relation to soil structure. Pol. J. Environ. Stud. 2013, 22, 1387-1391.

9. Dias Moreira, S.; Cabral França, A.; Grazziotti, P.H.; Soares Leal, F.D.; de Barros Silva, E. Arbuscular mycorrhizal fungi and phosphorus doses on coffee growth under a non-sterile soil. Rev. Caatinga 2019, 32, 72-80. [CrossRef]

10. Mishra, J.; Arora, N.K. Bioformulations for plant growth promotion and combating phytopathogens: A sustainable approach. In Bioformulations: For Sustainable Agriculture; Arora, N., Mehnaz, S., Balestrini, R., Eds.; Springer: Berlin/Heidelberg, Germany, 2016; pp. 3-33. [CrossRef]

11. Puigdefábregas, J.; Mendizabal, T. Perspectives on desertification: Western Mediterranean. J. Arid Environ. 1998, 39, 209-224. [CrossRef]

12. Avila-Salem, M.E.; Montesdeoca, F.; Orellana, M.; Pacheco, K.; Alvarado, S.; Becerra, N.; Marín, C.; Borie, F.; Aguilera, P.; Cornejo, P. Soil biological properties and arbuscular mycorrhizal fungal communities of representative crops established in the Andean region from Ecuadorian highlands. J. Soil Sci. Plant Nutr. 2020, 20, 2156-2163. [CrossRef]

13. Figueiredo, M.d.V.B.; Bonifacio, A.; Rodrigues, A.C.; de Araujo, F.F.; Stamford, N.P. Beneficial microorganisms: Current challenge to increase crop performance. In Bioformulations: For Sustainable Agriculture; Arora, N., Mehnaz, S., Balestrini, R., Eds.; Springer: Berlin/Heidelberg, Germany, 2016; pp. 53-70. [CrossRef]

14. Arif, I.M.; Batool, M.; Schenk, P.M. Plant Microbiome Engineering: Expected Benefits for Improved Crop Growth and Resilience. Trends Biotechnol. 2020, 38, 1385-1396. [CrossRef]

15. Quiza, L.; St-Arnaud, M.; Yergeau, E. Harnessing phytomicrobiome signaling for rhizosphere microbiome engineering. Front. Plant Sci. 2015, 6. [CrossRef]

16. FAOSTAT. Food and Agriculture Organization of the United Nations; FAO Database: Rome, Italy, 2021. [CrossRef]

17. Velivelli, S.L.; De Vos, P.; Kromann, P.; Declerck, S.; Prestwich, B.D. Biological control agents: From field to market, problems, and challenges. Trends Biotechnol. 2014, 32, 493-496. [CrossRef]

18. Bhattacharyya, P.N.; Jha, D.K. Plant growth-promoting rhizobacteria (PGPR): Emergence in agriculture. World J. Microbiol. Biotechnol. 2012, 28, 1327-1350. [CrossRef]

19. Timmusk, S.; Paalme, V.; Pavlicek, T.; Bergquist, J.; Vangala, A.; Danilas, T.; Nevo, E. Bacterial distribution in the rhizosphere of wild barley under contrasting microclimates. PLOS ONE 2011, 6, e17968. [CrossRef] [PubMed]

20. Jimenez-Salgado, T.; Fuentes-Ramirez, L.E.; Tapia-Hernandez, A.; Mascarua-Esparza, M.A.; Martinez-Romero, E.; CaballeroMellado, J. Coffea arabica L., a new host plant for Acetobacter diazotrophicus, and isolation of other nitrogen-fixing acetobacteria. Appl. Environ. Microbiol. 1997, 63, 3676-3683. [CrossRef]

21. Kejela, T.; Thakkar, V.R.; Thakor, P. Bacillus species (BT42) isolated from Coffea arabica L. rhizosphere antagonizes Colletotrichum gloeosporioides and Fusarium oxysporum and also exhibits multiple plant growth promoting activity. BMC Microbiol. 2016, 16, 277. [CrossRef]

22. Alcarraz Curi, M.; Heredia Jiménez, V.; Julian Ibarra, J.P. Cepas bacterianas nativas con actividades promotoras del crecimiento vegetal aisladas de la rizósfera de Coffea spp. en Pichanaqui, Perú. Biotecnol. Veg. 2019, 19, 285-295.

23. Cisneros, C.; Franco, J.M.; Fernandez, M.R.; Fuenmayor, J.C. Influencia de microorganismos en la disponibilidad de fósforo en plántulas de café (Coffea arabica). Biotecnol. Sect. Agropecu. Agroind. 1997, 15, 19-26. [CrossRef] 
24. Srivastava, M.P.; Sharma, S. Potential of PGPR bacteria in plant disease management. Biol. Control. Prev. Food Deterior. 2014, 87-116. [CrossRef]

25. Castillo, J.M.; Casas, J.; Romero, E. Isolation of an endosulfan-degrading bacterium from a coffee farm soil: Persistence and inhibitory effect on its biological functions. Sci. Total Environ. 2011, 412, 20-27. [CrossRef]

26. Martinez, S.J.; Bressani, A.P.P.; Dias, D.R.; Simão, J.B.P.; Schwan, R.F. Effect of bacterial and yeast starters on the formation of volatile and organic acid compounds in coffee beans and selection of flavors markers precursors during wet fermentation. Front. Microbiol. 2019, 10, 1287. [CrossRef]

27. Muleta, D.; Assefa, F.; Börjesson, E.; Granhall, U. Phosphate-solubilising rhizobacteria associated with Coffea arabica L. in natural coffee forests of southwestern Ethiopia. J. Saudi Soc. Agric. Sci. 2013, 12, 73-84. [CrossRef]

28. Srigandha, D.; Venkatesha, J.; Shetty, G.R.; Biradar, I.; Manjunath, G.; Kulkarni, S. Study of Suitability of Containers and Rooting Media for Growth and Rooting of Coffee Seedlings (Coffea arabica cv. Chandragiri). Int. J. Curr. Microbiol. App. Sci. 2017, 6, 527-530. [CrossRef]

29. Hoe, P.C.K.; Halimi, M.S.; Khairuddin, A.R.; Che, I.; Megat, W. Effects of gamma-irradiated Acinetobacter calcoaceticus on nitrogen and phosphorus uptake of green mustard (Brassica chinensis). Malays. J. Soil Sci. 2019, 23, 149-165.

30. Yuliatin, E.; Ardyati, T.; Suharjono, S. Effect of Soil Physicochemical Properties on PGPR Density at A Coffee Plantation in Malang, Indonesia. IOP Conf. Ser. Earth Environ. Sci. 2019, 391. [CrossRef]

31. Hassen, A.I.; Bopape, F.; Sanger, L. Microbial inoculants as agents of growth promotion and abiotic stress tolerance in plants. In Microbial Inoculants in Sustainable Agricultural Productivity; Springer: Berlin/Heidelberg, Germany, 2016; pp. 23-36. [CrossRef]

32. Bertolini, V.; Montaño, N.M.; Chimal Sánchez, E.; Varela Fregoso, L.; Gómez Ruiz, J.; Martínez Vázquez, J.M. Abundancia y riqueza de hongos micorrizógenos arbusculares en cafetales de Soconusco, Chiapas, México. Rev. Biol. Trop. 2018, 66, 91-105. [CrossRef]

33. Caldwell, A.C.C.; Silva, L.C.F.S.; da Silva, C.C.d.S.; Ouverney, C.C. Prokaryotic Diversity in the Rhizosphere of Organic, Intensive, and Transitional Coffee Farms in Brazil. PLoS ONE 2015, 10, e0106355. [CrossRef]

34. Boone, D.R.; Castenholz, R.W. Bergey's Manual of Systematic Bacteriology. Volume One: The Archaea and the Deeply Branching and Phototrophic Bacteria; Springer: New York, NY, USA, 2011; Volume 2, p. 722.

35. Barrera, J.; Arango, G. Uso y Manejo de las Micorrizas: Investigación en Cultivos. Available online: https://www.engormix.com/ agricultura/articulos/uso-manejo-micorrizas-investigacion-t32322.htm (accessed on 5 January 2021).

36. Aguirre-Medina, J.F.; Moroyoqui-Ovilla, D.M.; Mendoza-López, A.; Cadena-Iñiguez, J.; Avendaño-Arrazate, C.H.; AguirreCadena, J.F. Hongo endomicorrízico y bacteria fijadora de nitrógeno inoculadas a Coffea arabica en vivero. Agron. Mesoam. 2011, 22,71-80. [CrossRef]

37. Prates Júnior, P.; Moreira, B.C.; da Silva, M.d.C.S.; Veloso, T.G.R.; Stürmer, S.L.; Fernandes, R.B.A.; Mendonça, E.d.S.; Kasuya, M.C.M. Agroecological coffee management increases arbuscular mycorrhizal fungi diversity. PLoS ONE 2019, 14, e0209093. [CrossRef]

38. Reetha, D.; Kumaresan, G.; John Milton, D. Studies to improve the shelf life of Azospirillum lipoferum immobilized in alginate beads. Int. J. Recent Sci. Res. 2014, 5, 2178-2182.

39. Sahu, P.K.; Gupta, A.; Singh, M.; Mehrotra, P.; Brahmaprakash, G. Bioformulation and fluid bed drying: A new approach towards an improved biofertilizer formulation. In Eco-Friendly Agro-Biological Techniques for Enhancing Crop Productivity; Springer: Berlin/Heidelberg, Germany, 2018; pp. 47-62. [CrossRef]

40. Swapna, G.; Divya, M.; Brahmaprakash, G. Survival of microbial consortium in granular formulations, degradation and release of microorganisms in soil. Ann. Plant. Sci. 2016, 5, 1348-1352. [CrossRef]

41. Zavala, J.; Alcarraz, M.; Julian, J. Evaluación para la producción de Azotobacter sp. promotor de crecimiento para cultivos de Coffea arabica. Cienc. Investig. 2020, 23, 45-50. [CrossRef]

42. Lee, S.-K.; Lur, H.-S.; Lo, K.-J.; Cheng, K.-C.; Chuang, C.-C.; Tang, S.-J.; Yang, Z.-W.; Liu, C.-T. Evaluation of the effects of different liquid inoculant formulations on the survival and plant-growth-promoting efficiency of Rhodopseudomonas palustris strain PS3. Appl. Microbiol. Biotechnol. 2016, 100, 7977-7987. [CrossRef] [PubMed]

43. Lobo, C.B.; Tomás, M.S.J.; Viruel, E.; Ferrero, M.A.; Lucca, M.E. Development of low-cost formulations of plant growth-promoting bacteria to be used as inoculants in beneficial agricultural technologies. Microbiol. Res. 2019, 219, 12-25. [CrossRef]

44. Smith, S.E.; Read, D.J. Mycorrhizal Symbiosis; Academic Press: Cambridge, MA, USA, 2010.

45. Soudzilovskaia, N.A.; van Bodegom, P.M.; Terrer, C.; van't Zelfde, M.; McCallum, I.; McCormack, M.L.; Fisher, J.B.; Brundrett, M.C.; de Sá, N.C.; Tedersoo, L. Global mycorrhizal plant distribution linked to terrestrial carbon stocks. Nat. Commun. 2019, 10, 1-10. [CrossRef]

46. Kivlin, S.N.; Hawkes, C.V.; Treseder, K.K. Global diversity and distribution of arbuscular mycorrhizal fungi. Soil Biol. Biochem. 2011, 43, 2294-2303. [CrossRef]

47. Vallejos-Torres, G.; Arévalo, L.; Iliquin, I.; Solis, R. Respuesta en campo de clones de café a la inoculación con consorcios de hongos micorrízicos arbusculares en la región Amazonas, Perú. Inf. Tecnol. 2019, 30, 73-84. [CrossRef]

48. Repoma, M.; Elizabeth, V. Biogeografía de Hongos Micorrízicos Arbusculares (HMA) en el Cultivo de Café (Coffea arabica L.) en la Región San Martín; Título de Ingeniero Agrónomo, Universidad Nacional de San Martín: Tarapoto, Perú, 2017.

49. Mahdi, S.S.; Hassan, G.; Samoon, S.; Rather, H.; Dar, S.A.; Zehra, B. Bio-fertilizers in organic agriculture. J. Phytol. 2010, 2, 42-54. 
50. Gavilanes Velasco, A.S. Evaluación de Complejos Micorrízicos Asociados al Cultivo de Plántulas de Café (Coffea canephora). Bachelor's Thesis, UTB, Babahoyo, Ecuador, 2019.

51. Urgiles-Gómez, N.; Guachanamá-Sánchez, J.; Granda-Mora, I.; Robles-Carrión, Á.; Encalada-Cordova, M.; Loján-Armijos, P.; Avila-Salem, M.E.; Hurtado-Trejo, L.; Poma-López, N.; Collahuazo-Reinoso, Y. Caracterización morfológica de hongos micorrízicos arbusculares (HMA) asociados al café en sistemas agroforestales de la provincia de Loja, Ecuador. Bosques Latid. Cero 2020, 10, 137-145.

52. Fitter, A.; Helgason, T.; Hodge, A. Nutritional exchanges in the arbuscular mycorrhizal symbiosis: Implications for sustainable agriculture. Fungal Biol. Rev. 2011, 25, 68-72. [CrossRef]

53. Fonseca, A.J.; Freitas, A.F.d.; Carvalho, G.R.; Carneiro, M.A.C.; Vilela, D.J.M.; Fassio, L.d.O. Arbuscular mycorrhizal fungus on the initial growth and nutrition of Coffea arabica L. genotypes. Ciência Agrotecnol. 2019, 43. [CrossRef]

54. Fonseca, A.J.; Tassone, G.A.T.; Carneiro, M.A.C.; Carvalho, G.R.; Carvalho, C.H.S.; Botelho, C.E. Roles of arbuscular mycorrhizal fungi on acclimatization of clones of Coffea arabica L. produced by somatic embryogenesis. Ciência Agrotecnol. 2020, 44. [CrossRef]

55. Montesdeoca, F.; Ávila, M.; Quishpe, J.; Borie, F.; Cornejo, P.; Aguilera, P.; Alvarado, S.; Espinosa, J. Early changes in the transition from conventional to no-tillage in a volcanic soil cultivated with beans (Phaseolus vulgaris L.). Chil. J. Agric. Anim. Sci. (Agro-Cienc.) 2020, 36, 181-189. [CrossRef]

56. Mensah, J.A.; Koch, A.M.; Antunes, P.M.; Kiers, E.T.; Hart, M.; Bücking, H. High functional diversity within species of arbuscular mycorrhizal fungi is associated with differences in phosphate and nitrogen uptake and fungal phosphate metabolism. Mycorrhiza 2015, 25, 533-546. [CrossRef] [PubMed]

57. Pellegrino, E.; Bedini, S. Enhancing ecosystem services in sustainable agriculture: Biofertilization and biofortification of chickpea (Cicer arietinum L.) by arbuscular mycorrhizal fungi. Soil Biol. Biochem. 2014, 68, 429-439. [CrossRef]

58. Trejo-Aguilar, D.; Banuelos, J. Isolation and Culture of Arbuscular Mycorrhizal Fungi From Field Samples. Methods Mol. Biol. 2020, 2146, 1-18. [CrossRef]

59. Adholeya, A.; Tiwari, P.; Singh, R. Large-scale inoculum production of arbuscular mycorrhizal fungi on root organs and inoculation strategies. In In Vitro Culture of Mycorrhizas; Springer: Berlin/Heidelberg, Germany, 2005; pp. 315-338. [CrossRef]

60. Da Rosa, S.; McDonald, M.; Veiga, A.; Vilela, F.d.L.; Ferreira, I. Staging coffee seedling growth: A rationale for shortening the coffee seed germination test. Seed Sci. Technol. 2010, 38, 421-431. [CrossRef]

61. Eira, M.T.; Silva, E.; De Castro, R.D.; Dussert, S.; Walters, C.; Bewley, J.D.; Hilhorst, H.W. Coffee seed physiology. Braz. J. PlantPhysiol. 2006, 18, 149-163. [CrossRef]

62. Moreira, S.D.; França, A.C.; Rocha, W.W.; Tibães, E.S.; Neiva, E. Inoculation with mycorrhizal fungi on the growth and tolerance to water deficit of coffee plants. Rev. Bras. Eng. Agríc. Ambient. 2018, 22, 747-752. [CrossRef]

63. Basiru, S.; Mwanza, H.P.; Hijri, M. Analysis of arbuscular mycorrhizal fungal inoculant benchmarks. Microorganisms 2021, 9, 81. [CrossRef]

64. Zorzetti, J.; Ricietto, A.P.S.; Fazion, F.A.P.; Meneghin, A.M.; Neves, P.M.O.J.; Vilas-Boas, L.A.; Vilas-Bôas, G.T. Isolation, morphological and molecular characterization of Bacillus thuringiensis strains against Hypothenemus hampei Ferrari (Coleoptera: Curculionidae: Scolytinae). Rev. Bras. Entomol. 2018, 62, 198-204. [CrossRef]

65. Urgiles, N.; Strauß, A.; Loján, P.; Schüßler, A. Cultured arbuscular mycorrhizal fungi and native soil inocula improve seedling development of two pioneer trees in the Andean region. New For. 2014, 45, 859-874. [CrossRef]

66. Ramírez-Rodríguez, R.F.; Castañeda-Hidalgo, E.; Robles, C.; Santiago-Martínez, G.M.; Pérez-León, M.I.; Lozano-Trejo, S. Efectividad de Biofungicidas para el control de la roya en plántulas de café. Rev. Mex. Cienc. Agrícolas 2020, 11, 1403-1412. [CrossRef]

67. Cacefo, V.; Araújo, F.F.d.; Pacheco, A.C. Biological control of Hemileia vastatrix Berk. \& Broome with Bacillus subtilis Cohn and biochemical changes in the coffee. Coffee Sci. Lavras 2016, 11, 567-574.

68. Urgiles, N.; Haug, I.; Setaro, S.; Aguirre, N. Introduction to Mycorrhizas in the Tropics with Emphasis on the Montane Forest in Southern Ecuador; Universidad Nacional de Loja: Loja, Ecuador, 2016; 117p. 